\title{
Hard Machinable Machining of Cobalt-based Superalloy
}

Robert Cep ${ }^{1}$, Adam Janasek ${ }^{1}$, Jana Petru ${ }^{1}$, Lenka Cepova ${ }^{1}$, Andrej Czan ${ }^{2}$, Jan Valicek ${ }^{3}$

${ }^{1}$ VSB - Technical University of Ostrava, Faculty of Mechanical Engineering, Department of Machining and Assembly, 17. listopadu 15/2172, 70833 Ostrava - Poruba, Czech Republic. robert.cep@vsb.cz

2 Faculty of Mechanical Engineering of University of Zilina, Department of Machining and Manufacturing Technology, Univerzitna 1, 01026 Zilina, Slovak Republic.

3 VSB - Technical University of Ostrava, Faculty of Mining and geology, Institute of Physics, 17. listopadu 15/2172, 70833 Ostrava - Poruba, Czech Republic.

The main aim is testing the basic properties of cobalt super alloys, under its own brand name HAYNES, marking No. 188, at machining and propose the most suitable cutting materials and machining parameters. The superalloys are developed for elevation of temperature service where relatively severe mechanical stressing is encountered and high surface stability is frequently required. The cobalt-based alloys have been in use for several decades in the manufacturing of various components. Although technology development rises in chipless machining such as moulding, precision casting and other manufacturing methods, the machining is still number one, at piece production which is typical for energy and chemical engineering. The driving force for their development still has been requirement of higher operating temperatures for many manufacturing fields in industry area.

Keywords: geometric accuracy, testing, milling machine, tool wear, superalloy

\section{References}

[1] BILÍK, O. Obrábění I - 1. díl. Ostrava: VŠB-Technical University of Ostrava, (2001). p. 136. ISBN 80-7078-8119.

[2] Corporate literature: Haynes Inernational. High-temperature alloy. England Parkhouse Street. Haynes 188® Alloy. 1986.

[3] BENES, J. Tips For Machining Super Alloys. American Machinist [online]. [cit. 2012-10-22]. Available from: http://americanmachinist.com/cutting-tools/tips-machining-super-alloys

[4] NESLUŠAN, M. and CZÁN, Aj. Machining of difficult-to-machine materials. 1. publication. Žilina: University of Žilina, 2002. p. 127.

[5] ČEP, R. Incerasing of manufacturing precision by powerful cutting tools. In WORKSHOP for Faculty of Mechanical Engineering 2002. Ostrava: VŠB - TU Ostrava, 2002, p. 13-16. ISBN 80-248-0051-9.

[6] BILÍK, O. and KUBIŠ, M. Theory manual into practice machining. 1. publication. Ostrava: Publishing centre: VŠB, 1991.

[7] ČEP, R., KOUŘIL, K., MRKVICA, I., JANÁSEK, A. and PROCHÁZKA, J. Zkoušky nástrojů Kyocera v podmínkách přerušovaného řez. Strojírenská technologie. XV, No. 3, p. 51-58, (2010). ISSN 1211-4162.

[8] SANDVIK Coromant, Technical Editorial dept., Modern Metal Cutting - A Practical Handbook. Tofters Tryckery AB, Swede, 1994, p. 927, ISBN 91-972290-0-3

[9] HAYNES 188 ALLOY: High-temperature alloys [online]. Global Headquarters: 1020 West Park Avenue, Kokomo, Indiana 46904-9013 (USA) [cited: 2013-03-31]. Available from: http://www.haynesintl.com/pdf/h3001.pdf

[10] ČEP, R., PAGÁČ, M., PETRŮ, J. and ZLÁMAL, Tomáš. Porovnání výrobních nákladů vložky lisovací formy vyráběné technologiemi frézování a elektroerozivního obrábění. Strojírenská technologie. XVII, No. 3, p. 149154, (2012). ISSN 1211-4162.

[11] MÁDL, Jan and SUTANTO, H. Hard Machining and Residual Stresses. Manufacturing Technology. VII. No. 1, p. 5-10, (2007). ISSN 1213-2489.

[12] KUNDRAK, J., VARGA, G., DESZPOTH, I. and MOLNAR, V. Some aspects of the hard machining of bore holes, Applied Mechanics and Materials 309, pp. 126-132, (2013).

[13] JANASEK, A., CEP, R. and BRYCHTA, J. Checking the geometric accuracy of a machine tool for selected geometric parameters. Acta Polytechnica. 52, No. 4. p. 68-72. ISSN 1210-2709. 